\title{
Effect of Transtheoretical Model Based Intervention Program on Cigarette Smoking Cessation among Technical Secondary School Male Students in Zagazig City
}

Randa M. Said ${ }^{1}$, Noha M. Abdelsalam ${ }^{2 *}$

${ }^{1}$ Department of Family Medicine, Faculty of Medicine, Zagazig University

${ }^{2}$ Department of Public Health and Preventive Medicine, Faculty of Medicine, Zagazig University

\section{Abstract:}

Background: Interventions via cognitive-behavioral strategies are promising in smoking cessation among adolescents, by using the Transtheoretical model (TTM). Objective: To assess the effect of TTM- intervention program on smoking health risk, stages and process of change in smoking cessation, , decisional balance, and self-efficacy among technical secondary school male students in Zagazig city. Methods: A quasi-experimental study conducted in two randomly selected technical secondary schools in Zagazig city, Sharkia Governorate, Egypt. Male smokers from one school assigned as an experimental group and those from the other school as a control group. The experimental group received interventions based on the stage of behavior change through group counseling followed by individual phone counseling for 10 months. Intervention evaluation was done through self-reported questionnaires assessing knowledge and TTM outcomes. Results: After the intervention, participants in the experimental group (32\%) progressed from lower to higher stages of behavior change compared with those in the control group (1.9\%). The participants who reached action/maintenance stage were $13.9 \%$ in the experimental group versus $1.9 \%$ in the control group. There was a significant difference between two groups in the mean scores of knowledge, processes of change, decisional balance and self efficacy $(\mathrm{P}<0.000)$. Conclusion: The TTM-based smoking cessation intervention program was effective in inducing a positive movement in the stages of behavior change among adolescent smokers through improving knowledge, experiential and behavioral processes, decisional balance and self-efficacy.

Keywords: Adolescents, Decisional balance, Process of change, Stage of change, Self-efficacy.

Introduction: Smoking is the most important preventable cause of morbidity and mortality worldwide. The World Health Organization reported an increasing trend in prevalence of tobacco smoking among Egyptian male adolescents from $23.8 \%$ in the year of 2000 to $29.9 \%$ in 2010 and predicted to reach $43.7 \%$ by $2025 .^{(1)}$ Early initiation of cigarette smoking during adolescence is a strong predictor of smoking in adulthood.(2) Over
$80 \%$ of regular adult smokers begin tobacco use before the age of $18 .^{(3)}$ Initiation of cigarette smoking in adolescence will be associated with difficulties to quit smoking in adulthood. $^{(4)}$ Adolescent smokers tend to underestimate the addictive nature of nicotine although they rapidly develop nicotine dependence within 2-3 years. ${ }^{(5)}$ A significant number of adolescents who use illicit drugs smoked cigarettes first. ${ }^{(6)}$ Therefore, 
prevention and control of smoking among adolescents should be focused on intervention.

Some meta-analysis studies found smoking cessation interventions among adolescents which applied cognitivebehavioral strategies were promising but did not recommend any specific model for widespread implementation. ${ }^{(7)}$ The transtheoretical model is a stage-based theory of behavior change. The stages of change (SOC) which represents the core construct of the model are pre-contemplation, contemplation, preparation, action, and maintenance. Going through these stages is hypothesized by the processes of change (POC), decisional balance, and temptation/self-efficacy which represent the other constructs of the model. ${ }^{(8)}$

The TTM has been widely used in research. Findings from trials comparing TTM- interventions to control were disappointing either negative or positive. However, the evidence from these trials is unclear because many of them have stage specific rather than the entire TTM stages. Moreover, negative trials might be attributed to the formulation of the intervention rather than TTM theory. ${ }^{(9)}$

The intervention program used all the TTM constructs. The research aims to measure the effectiveness of the TTM in adolescent smoking behavior. The main study objective to assess the effect of TTM-based on knowledge intervention of smoking health risk, stages of smoking cessation, processes of change, decisional balance, and self-efficacy among technical secondary school male students in Zagazig city.

Subjects and methods: This study is a quasiexperimental study. It was conducted on two experimental and control groups over a period of 12 months from September 2016 to October 2017. Through simple random sampling, two out of five technical secondary schools for males at Zagazig city selected as an experimental group and a control group. The sample size was calculated through EpiInfo (Epidemiological information package) software version 6 , according to the following data; confidence interval $95 \%$, power $80 \%$, effect $25 \%$, the effect size due to the interval $21 \%$ and the risk ratio $4.4,{ }^{(7)}$ so the calculated sample size was 148 subjects.

Sample size was divided equally between experimental and control groups. A total sample of 113 participants (59 in the experimental group and 54 in the control group) completed all assessments used for final analysis. The study included all the recruited smokers regardless their gender and age. The participants with lost to phone 
contact, inability to complete post-test, absence from group counseling sessions and refusing twice to accept phone counseling were excluded from the study.

Tools of the study: The tools of the study included the following:-

1. Smoking assessment questionnaire: it assessed the smoking history and nicotine dependence level according to Modified Fagerström Tolerance Questionnaire for Adolescents. ${ }^{(10)}$

2. TTM constructs questionnaires: It was translated into Arabic then validated through a back translation technique and pilot testing, included:

a. Stages of change questionnaire: Participants selected one of five statements best representing their current intentions of quitting smoking including pre-contemplation (no intention to quit within the next 6 months), contemplation (consider quitting in the next 6 months), preparation (plan to quit in the next 30 days), action (quit smoking within the last 6 months) and maintenance (quit smoking more than 6 months ago). ${ }^{(8)}$

b. Smoking Decisional Balance scale: It was a 20-items self-report measure of a participant's pros and cons of smoking. The participants rated the degree of importance of each statement to their decision to smoke on a five-point Likeret scale with total score $=100$ points divided equally between pros and cons. Reliability Cronbach's Alphas ranged from (0.560.67) for Pros and (0.51-0.61) for Cons. ${ }^{(11)}$

c. Smoking cessation self-efficacy scale: It was a 20-items self-report measure scored on a five-point Likeret scale with total score $=100$ points. It examined a degree of confidence for smokers to resist the temptation of smoking. Reliability Cronbach's Alphas ranged from 0.92-0.95. ${ }^{(12)}$

d. Process of change questionnaire: Experiential and behavioral processes of change were assessed by a 40 items self-report measure scored on a fivepoint Likert scale with total score= 200 points divided equally between Experiential and behavioral processes of change. The participants indicated how often they may use each thought or situation to help them avoid smoking in the last month. Reliability Cronbach's Alphas ranged from 0.690.92. ${ }^{(13)}$

3. Knowledge and perception of health risks of smoking questionnaire: It was 
adapted from Yang et al. Translated into Arabic then validated through a back translation technique and pilot testing. It consisted of two parts: (a) eight questions on knowledge about health hazards of smoking. Responses were coded as 0 for 'no/don't know' versus 1 for 'yes', (b) six questions on risk perception of smoking including agreement with three statements according to a five-point Likert scale. Three additional questions with response categories of $0=$ 'don't know', $1=$ 'not at all', 2= 'a little', and 3= 'very much'. The total score of knowledge and perception was 32 points with higher scores indicating better knowledge and perception. ${ }^{(14)}$ Pilot study was conducted in September 2016 on 15 students who were excluded from the study to check the validity of the questionnaires.

Field-work: It passed through three phases:

First phase: pre-intervention (assessment phase): It took the $1^{\text {st }}$ two weeks of October 2016 where the research tools were distributed in both experimental and control groups. The participants were directed if they had a problem with the completion of the questionnaires. Data were collected then analyzed and used to guide designing the intervention.
Second phase: Intervention (TTM based intervention program): The intervention carried out for the experimental group during the period from the middle of October 2016 to end of November 2016 with follow up for ten months for each participant. The control group did not receive any intervention. In the school selected as the experimental group, the participants were divided into groups according to their stage of change. The intervention was in the form of group counseling sessions followed by individual monthly phone counseling.

All sessions held in the teachers' meeting room during the students' activity periods. Each session lasted 45 minutes. The interventional program activities were tailored on the stage of change taking into consideration the other psychological constructs of the model as summarized in Appendix(1).

The interventional program tools included:

-Video clip consisted of two sections as follow: Section A showing physical, psychological, and social effects of smoking, which was demonstrated by participants at the pre-contemplation stage; Section B showing practical strategies to quit smoking which was demonstrated by all participants. 
- The role-playing method, the peer education method, quizzes, and exercises were used to promote the smoking resistant skills and problem-solving skills.

- A handbook entitled "self-help to quit smoking in adolescents" was developed and distributed among all participants. It instructs participants about stages of change so they can stage themselves and then provides information appropriate to the stages of change.

3rd phase: post-intervention (Evaluation phase): It was conducted one year after the assessment phase for both the experimental and control groups i.e. in October 2017. This phase took two weeks where reassessing the participants by the same questionnaires used before the intervention was done. The data obtained from the questionnaires were collected, analyzed and compared to the control group.

Ethical considerations: The research protocol was approved by Ethics Committee of Faculty of Medicine, Zagazig University, Egypt and the reference number is $\mathrm{ZU}$ IRB\#:4502. Before carrying out the study, the necessary official permission obtained. An informed written consent obtained from the recruited students. Total confidentiality of any given information assured.
Data Management: By the Statistical Product and Service Solution (SPSS) 15.0 (SPSS Inc., Chicago, IL, USA), the appropriate statistical tests including Chisquare test, Fisher exact test, Wilcoxon sign rank test, paired-t test, and independent- $t$ test with 0.05 significance level were used to measure the statistical difference between the pre and post intervention and between the experimental and control groups.

Results: There were no significant differences between experimental and control groups in all smoking assessment variables (Table-1). Before the intervention, no significant differences were found between experimental and control groups in the distribution of participants in different stages of change and in the mean scores of knowledge and other TTM constructs. After the intervention, more participants in the experimental group (32\%) progressed from lower to higher stages of behavior change compared with those in the control group (1.9\%).

Also, fewer participants in the experimental group (3.4\%) had regressed in the stage of behavior change compared with those in the control group (9.2\%). Furthermore, the participants who reached action/maintenance stage were $13.9 \%$ in the experimental group versus $1.9 \%$ in the control group. 
Also, the differences between the experimental and control groups were statistically significant in mean knowledge score $(\mathrm{p}=0.000)$, mean scores for experiential processes $(\mathrm{p}=0.04)$ and behavioral processes $(p=0.000)$, mean scores of decisional balance pros and cons $(\mathrm{p}=0.000)$ and mean score of self-efficacy $(\mathrm{p}=0.000)$ (Table- $2,3,4)$.

Discussion: Before the program, there were no significant differences between experimental and control groups in all smoking assessment variables, and in the mean score of knowledge and TTM constructs, so any improvement in the experimental group after the program has been performed. After the program, the participants who reached the target behavior stage (action/maintenance) were $13.9 \%$ in the experimental group versus $1.9 \%$ in the control group indicating program effectiveness.

Prochaska et al. in 2001 reported that point prevalence smoking abstinence rates were $16.0 \%$ in the TTM arms and $12.6 \%$ in the control arm. ${ }^{(15)}$ Aveyard et al. in 2003 found that smoking abstinence rates were $2.1 \%$ in the TTM arm and $1.4 \%$ in the control arm measured 12 months from baseline. ${ }^{(16)}$ Koyun and Eroğlu in 2014 reported that the rate of smoking cessation in TTM based interventions in adults ranged from $4.5 \%$ to $39.5 \%{ }^{(17)} \mathrm{A}$ meta-analysis of 48 adolescent smoking cessation studies which applied cognitive-behavioral strategies found a significantly higher average intervention quit rate compared to the average control quit rate $(9.1 \%$ vs. $6.2 \%){ }^{(18)}$

Knowledge was measured as a determinant of behavior change. Its mean score was increased in the experimental group compared to the control group. This is consistent with Guo et al. in 2016 which concluded that TTM-based smoking cessation interventions were effective in the improvement of knowledge of smokers about smoking health risks. ${ }^{(19)}$

The processes of change, decisional balance, and self-efficacy act as essential markers of movement through stages of behavior change. After the intervention, the mean score of all these markers were indicating program effectiveness. Many studies have reported that effective interventions use different processes during different SOC. ${ }^{(13)}$

A meta-analysis of studies evaluating the process of change reported that cognitive processes such as "consciousness raising" were more effective among smokers at early stages of change i.e. the pre-contemplation and contemplation stages while behavioral processes such as "stimulus control" were more effective at late stages of change i.e. the 
action and maintenance stages. ${ }^{(20)}$ In precontemplation, the weight of cons of smoking cessation exceeds the pros. In contemplation, these two scales are about equal. In the advanced stages, the weight of pros of quitting exceeds the cons. ${ }^{(8)}$ one study reported high perceived self-efficacy after TTM based interventions ${ }^{(21)}$ while another study reported no statistical significance in the smoking cessation self-efficacy after TTM based intervention supposing that the effectiveness might reveal through a long-term period. (19)

Study Limitations: Limitations of this study were; firstly, lack of biochemical results (urine or saliva results) make the significance of results limited by the nature of self-report. Secondly, long-term follow-up may be needed to track the maintenance of smoking cessation behavior. Thirdly, small sample size and inclusion of adolescents from technical schools only may interfere with the generalization of results. Further studies with a larger sample size covering all sectors of adolescent smokers are needed to prove the estimate of effect of the TTM intervention program.

Conclusions and recommendations: The TTM based smoking cessation intervention program was effective in inducing a positive movement in the stages of behavior change among adolescent smokers. It was also effective in improving knowledge, experiential and behavioral processes, decisional balance and self-efficacy among them. For this reason, the model is recommended to use in smoking cessation programs of adolescents.

Acknowledgments: We would like to thank the school managers, teachers, and the participating students for their cooperation.

Funding: The authors financed this research totally.

Conflict of Interests: There is no conflict of interest to be declared.

\section{References:}

1. World Health Organization. WHO global report on trends in prevalence of tobacco smoking, 2015.Available at: http://www.who.int/iris/handle/10665/156 262. Accessed on 17.03.2016.

2. Dalton MA, Beach ML, Ada-Mejia AM, Longacre MR, Matzkin AL, Sargent JD, et al. Early exposure to movie smoking predicts established smoking by older teens and young adults. Pediatrics 2009; 123:551-8.

3. US Department of Health and Human Services. Preventing Tobacco Use among Youth and Young Adults: A Report of the Surgeon General. Atlanta, GA: U.S. Department of Health and Human Services, Centers for Disease Control and 
Prevention, National Center for Chronic Disease Prevention and Health Promotion, Office on Smoking and Health, 2012 https://www.surgeongeneral.gov/library/re ports/preventing-youth-tobacco-use/fullreport.pdf. Accessed on 07.04.2016].

4. Husten CG. Smoking cessation in young adults. Am J Public Health 2007; 97 (8):1354-6.

5. Colby SM, Tiffany S, Shiffman S, Niaura RS. Measuring nicotine dependence among youth: a review of available approaches and instruments. Journal of Drug and Alcohol Dependence 2000; 59(Suppl 1):S23-S9.

6. Everett SA, Giovino GA, Warren $\mathrm{CW}$, Crossett L, Kann L. Other substance use among high school students who use tobacco. J Adolesc Health 1998; 23(5):289-96.

7. Gabble R, Babayan A, DiSante E, Schwartz R. Smoking Cessation Interventions for Youth: A Review of the Literature. Toronto: Ontario Tobacco $\underline{\text { Research Unit, February } 2015 .}$

8. Velicer WF, Prochaska JO, Fava JL, Rossi JS, Redding CA, Laforge RG, et al. Using the Transtheoretical Model for Populationbased Approaches to Health Promotion and Disease Prevention. Homeostasis in Health and Disease 2000; 40: 174-95.
9. Aveyard P, Massey L, Parsons A, Manaseki S, Griffin C. The effect of Transtheoretical Model based interventions on smoking cessation. Social Science and Medicine 2009; 68: 397-403.

10. Prokhorov AV, Koehly LM, Pallonen UE, Hudmon KS. Adolescent nicotine dependence measuring by the modified FagerstrÖm Tolerance Questionnaire at two time points. J Child Adolesc Subst Abuse 1998; 7(4):35-47.

11. Ward RM, Velicer WF, Rossi JS. Factorial invariance and internal consistency for the decisional balance inventory - short form. Addictive Behaviors 2004; 29: 953-8. Available at: https://habitslab.umbc.edu/files/2014/07/D ecisional-Balance-20item smoking.pd

12. Velicer WF, DiClemente CC, Rossi JS, Prochaska JO. Relapse situations and selfefficacy: An integrative model. Addictive Behaviors 1990; 15: 271-83. https://habitslab.umbc.edu/files/2014/07/S ASE20item.pdf

13. Prochaska JO, Velicer WF, DiClemente CC, Fava JL. Measuring the processes of change: Applications to the cessation of smoking. Journal of Consulting and Clinical Psychology 1988; 56:520-8. https://habitslab.umbc.edu/files/2014/07/P 
$\underline{\text { rocesses-of-Change-Questionnaire- }}$

40itemalc.pdf

14. Yang J, Hammond D, Driezen P, Fong G T, Jiang Y. Health knowledge and perception of risks among Chinese smokers and non-smokers: findings from the Wave 1 ITC China Survey. Tobacco Control 2010; 19(Suppl 2):i18-i23.

15. Prochaska JO, Velicer WF, Fava, JL, Ruggiero L, Laforge RG, Rossi JS, et al. Counselor and stimulus control enhancements of a stage-matched expert system intervention for smokers in a managed care setting. Preventive Medicine 2001; 32: 22-32.

16. Aveyard P, Griffin C, Lawrence PT, Cheng KK. A controlled trial of an expert system and self-help manual intervention based on the stages of change versus standard self-help materials in smoking cessation. Addiction 2003; 98, 345-54.

17. Koyun A, Eroğlu K. The transtheoretical model use for smoking cessation. European Journal of Research on Education 2014; Special Issue: Contemporary Studies in Social Science, 130- 4.

18. Sussman S, Sun P, Dent CW. A metaanalysis of teen cigarette smoking cessation. Health Psychology 2006; 25(5):549-57.
19. Guo S, Chang Y, Fu C, Hsu M. The effects of Transtheoretical Model based interventions on smoking cessation in Taiwan- A longitudinal study. Nursing research congress 2016.Available at: https://www.nursingrepository.org/bitstrea $\mathrm{m} /$ handle/10755/616530/64 accessed in 13-Dec-2017.

20. Rosen CS. Is the sequencing of change processes by stage consistent across health problems? A meta-analysis. Health Psychol 2000; 19:593-604.

21. Ulgen H, Ozturk C, Armstrong M. Effect of self-efficacy on Turkish children's perceptions of the advantages/disadvantages of smoking. Asian Pacific Journal of Cancer Prevention 2012; 13 (3):795-8. 
Table (1): Comparison of smoking assessment variables of participants in the control and experimental groups

\begin{tabular}{|c|c|c|c|}
\hline Variables & $\begin{array}{c}\text { Experimental group } \\
\mathrm{No}_{\mathrm{0}}=\mathbf{5 9}\end{array}$ & $\begin{array}{c}\text { Control } \\
\text { group } \\
\text { No }=54 \\
\end{array}$ & $P$ value \\
\hline $\begin{array}{l}\text { Age of the first-time smoking (years) } \\
\text { - } \quad \text { Range } \\
\text { - } \quad \text { Mean } \pm \mathrm{SD}\end{array}$ & $\begin{array}{c}11-14 \\
12.9 \pm 3.7\end{array}$ & $\begin{array}{c}12-14 \\
13.2 \pm 2.9\end{array}$ & $0.6^{\mathrm{a}}$ \\
\hline $\begin{array}{ll}\text { Duration of smoking(years) } \\
\text { - } & \text { Range } \\
\text { - } & \text { Mean } \pm \mathrm{SD} \\
& \text { Median }\end{array}$ & $\begin{array}{c}1-7 \\
3.5 \pm 1.8 \\
3\end{array}$ & $\begin{array}{c}1-6 \\
3.06 \pm 1.4 \\
3\end{array}$ & $0.116^{\mathbf{b}}$ \\
\hline $\begin{array}{l}\text { Number of cigarettes smoked per day } \\
\text { : } \text { Range } \\
\text { : } \text { Mean } \pm \text { SD } \\
\text { Median }\end{array}$ & $\begin{array}{c}4-20 \\
9.0 \pm 3.6 \\
9\end{array}$ & $\begin{array}{c}4-15 \\
8.7 \pm 3.2 \\
8\end{array}$ & $0.7^{\mathrm{b}}$ \\
\hline Family member who smoked N (\%) & $33(55.9)$ & $28(51.8)$ & $0.8^{\mathrm{c}}$ \\
\hline Friends who smoked $\mathrm{N}(\%)$ & $31(52.5)$ & $28(51.8)$ & $0.94^{\mathrm{c}}$ \\
\hline $\begin{array}{l}\text { Important reasons for smoking } \mathrm{N}(\%) \\
\text { - To achieve euphoria } \\
\text { - } \quad \text { To relieve stress } \\
\text { - } \\
\quad \text { Adventurism smoker family member or friend }\end{array}$ & $\begin{array}{c}8(13.5) \\
8(13.5) \\
23(39.1) \\
20(33.9)\end{array}$ & $\begin{array}{l}8(14.8) \\
10(18.5) \\
20(37.1) \\
16(29.6)\end{array}$ & $0.88^{\mathrm{c}}$ \\
\hline Subjects tried to quit smoking N (\%) & $35(59.3)$ & $31(57.4)$ & $0.83^{\mathrm{c}}$ \\
\hline $\begin{array}{l}\text { Past quit attempts description } \\
\text { 1- Number } \\
\text { - Range } \\
\text { - Mean } \pm \text { SD } \\
\text { - Median } \\
\text { 2- Duration(days) } \\
\text { - } \text { Range } \\
\text { - Mean } \pm \text { SD } \\
\text { - Median } \\
\text { 3- Method: } \\
\text { - Not assisted }\end{array}$ & $\begin{array}{c}1-3 \\
2.27 \pm 1.2 \\
2 \\
\\
1-5 \\
2.5 \pm 0.9 \\
2 \\
30(85.7) \\
\end{array}$ & $\begin{array}{c}1-4 \\
2.6 \pm 1.2 \\
3 \\
1-6 \\
2.2 \pm 0.97 \\
2 \\
26(83.9) \\
\end{array}$ & $0.11^{\mathbf{b}}$ \\
\hline Family support to stop smoking & $20(33.9)$ & $22(40.7)$ & $0.3^{\mathrm{c}}$ \\
\hline $\begin{array}{r}\text { FTND score }^{\mathbf{d}} \\
\text { Mean } \pm \text { SD }\end{array}$ & $3.9 \pm 1.1$ & $3.7 \pm 1.09$ & $0.3^{\mathrm{a}}$ \\
\hline
\end{tabular}

${ }^{a} \mathrm{P}$-values are based on Student $\mathrm{t}$ test

${ }^{\mathrm{b}} \mathrm{P}$-values are based on Mann-whitney test

${ }^{c} \mathrm{P}$-values are based on Chi-squared test

${ }^{\mathrm{d}}$ FTND: Fagerstrom Test for Nicotine Dependence 
Table (2): Comparison of participants' stage of change before and after intervention in the experimental and control groups

\begin{tabular}{|c|c|c|c|c|}
\hline & Stage of change & $\begin{array}{c}\text { Experimental group } \\
\mathrm{N}=59(\%)\end{array}$ & $\begin{array}{c}\text { Control group } \\
\mathrm{N}=54(\%)\end{array}$ & P value ${ }^{a}$ \\
\hline $\begin{array}{l}\text { Before } \\
\text { intervention }\end{array}$ & $\begin{array}{ll}\text { - } & \text { Precontemplation } \\
\text { - } & \text { Contemplation } \\
\text { - } & \text { Actionaration } \\
\text { maintenance }\end{array}$ & $\begin{array}{c}27(45.8) \\
22(37.3) \\
10(16.9) \\
0(0.0)\end{array}$ & $\begin{array}{c}24(44.4) \\
21(38.9) \\
9(16.7) \\
0(0.0)\end{array}$ & 0.99 \\
\hline $\begin{array}{l}\text { After } \\
\text { intervention }\end{array}$ & $\begin{array}{ll}\text { - } & \text { Precontemplation } \\
\text { - } & \text { Contemplation } \\
\text { - } & \text { Actioparation } \\
\text {-maintenance }\end{array}$ & $\begin{array}{l}17(28.8) \\
20(33.9) \\
14(23.7) \\
8(13.6)\end{array}$ & $\begin{array}{c}26(48.1) \\
22(40.7) \\
5(9.3) \\
1(1.9)\end{array}$ & 0.008 \\
\hline
\end{tabular}

${ }^{\text {a }} \mathrm{P}$-values are based on Fisher exact test

Table (3): Stage movement from pre-intervention to post-intervention in experimental and control groups

\begin{tabular}{|c|c|c|}
\hline Stage movement & $\begin{array}{c}\text { Experimental group } \\
\mathbf{N}=59(\%)\end{array}$ & $\begin{array}{c}\text { Control group } \\
\mathrm{N}=54(\%)\end{array}$ \\
\hline $\begin{array}{ll}\text { - } & \text { Progress } \\
\text { - } & \text { Stationary } \\
\text { - } & \text { Regress } \\
& \text { P value }\end{array}$ & $\begin{array}{c}32(54.2) \\
25(42.4) \\
2(3.4) \\
0.000\end{array}$ & $\begin{array}{c}1(1.9) \\
48(88.9) \\
5(9.2) \\
0.102\end{array}$ \\
\hline
\end{tabular}

a P-values are based on Wilcoxon signed ranked test 
Table 4: Comparison of mean of scores for Transtheoretical model constructs before and after intervention in the experimental and control groups

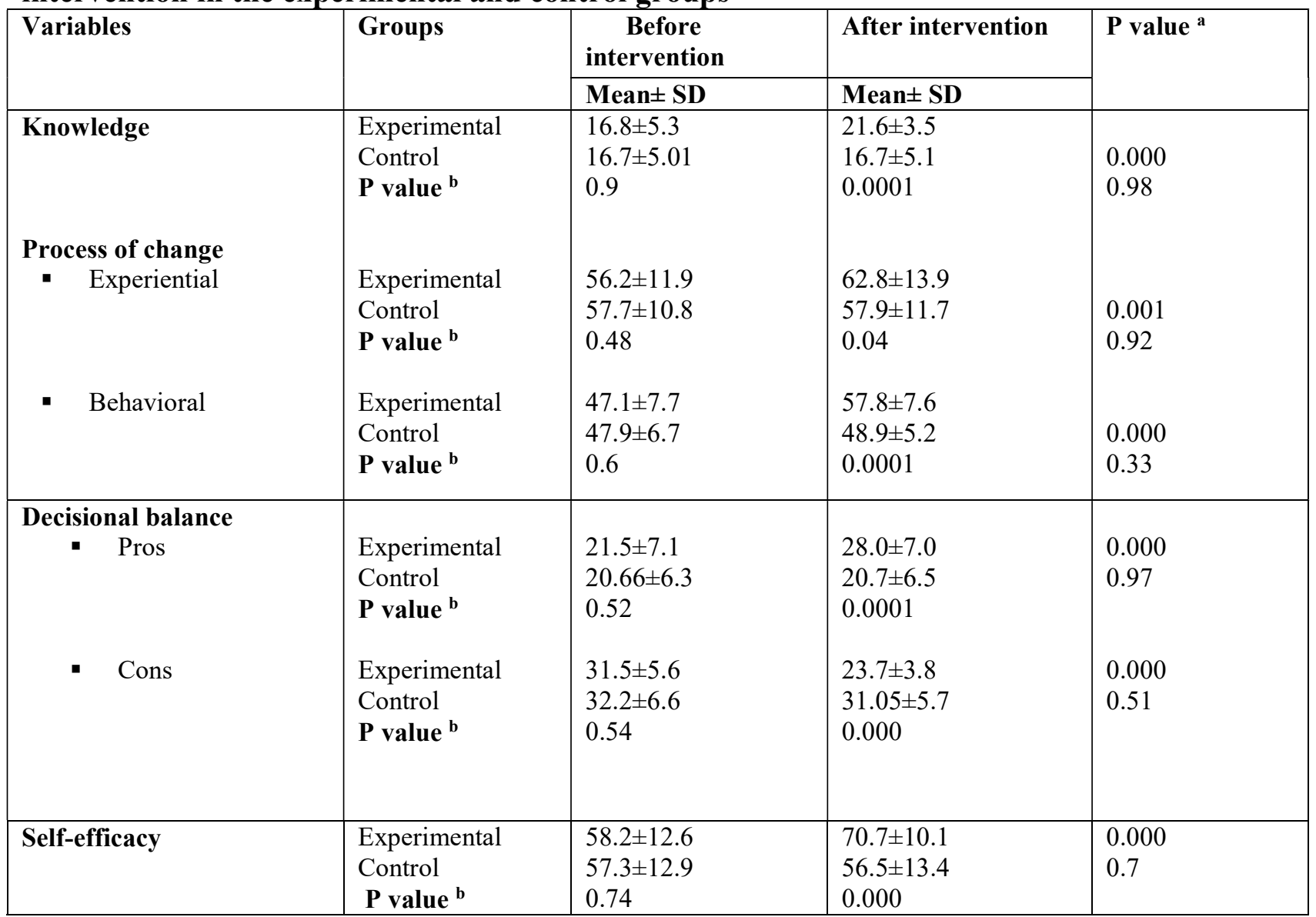

${ }^{\text {a }}$ P-values are based on Paired-t test

${ }^{b} \mathrm{P}$-values are based on Student t-test 
Appendix (1): Transtheoretical model theoretical constructs and interventional activities

\begin{tabular}{|c|c|c|}
\hline Stage of change & Processes of change & Intervention activities \\
\hline $\begin{array}{l}\text { Precontemplatio } \\
\text { n } \\
\text { (five sessions) }\end{array}$ & $\begin{array}{l}\text { Consciousness raising } \\
\text { Decisional balance }\end{array}$ & $\begin{array}{l}\text { 1. Educating the participants about definition and physiology of } \\
\text { addiction, contents of cigarette, influencing factors on initiation of } \\
\text { smoking, and negative effects of smoking. } \\
\text { 2. Recommending quitting with discussion of its benefits. } \\
\text { 3. Discussing strategies for quitting. }\end{array}$ \\
\hline $\begin{array}{l}\text { Contemplation } \\
\text { (three sessions) }\end{array}$ & $\begin{array}{l}\text { Environmental } \\
\text { reevaluation } \\
\text { Self-reevaluation }\end{array}$ & $\begin{array}{l}\text { 1. Exploring reasons for wanting to quit smoking. } \\
\text { 2. Discussing benefits and barriers to quitting tobacco. } \\
\text { 3. Discussing strategies for quitting. }\end{array}$ \\
\hline $\begin{array}{l}\text { Preparation } \\
\text { (two sessions) }\end{array}$ & $\begin{array}{l}\text { Stimulus Control } \\
\text { Counter Conditioning } \\
\text { Helping } \\
\text { Relationships } \\
\text { Self-efficacy } \\
\text { enhancement }\end{array}$ & $\begin{array}{l}\text { Discussing strategies for quitting including: } \\
\text { 1. Setting a definite quit date within one month of } 1^{\text {st }} \text { meeting with each } \\
\text { group through voting. } \\
\text { 2. Seeking social support. The participants were counseled to let family } \\
\text { members or other significant persons know that they had decided to quit } \\
\text { smoking on a certain date and taught how to ask others for help. } \\
\text { 3. Preparing the environment. The participants were counseled to remove } \\
\text { cigarettes, ashtrays, and other smoking-related things from their home, } \\
\text { Placing tip sheets on refrigerators as a reminder of not using tobacco and } \\
\text { to ask others not to smoke in their presence. } \\
\text { 4. Training on substitution behaviors e.g. Assertiveness training, Social } \\
\text { skills training, Anger control, Relaxation training, Problem solving to } \\
\text { deal with high-risk situations that promote relapse, performing a new } \\
\text { behavior (e.g., chewing on a toothpick, doing other things by hands) } \\
\text { instead of using tobacco. }\end{array}$ \\
\hline $\begin{array}{l}\text { Action/ } \\
\text { Maintenance }\end{array}$ & $\begin{array}{l}\text { Self-efficacy } \\
\text { enhancement }\end{array}$ & $\begin{array}{l}\text { 1. Monthly phone counseling started from the determined quit date for } \\
\text { ten months to provide support and resolve barriers for quitting. } \\
\text { 2. Asking the participants to report in a note the perceived benefits from } \\
\text { quitting, and current or anticipated difficulty in maintaining abstinence to } \\
\text { be able to discuss them with the researchers during contacts } \\
\text { 3. Continuing positive verbal reinforcement for those in Maintenance } \\
\text { stage } \\
\text { 4. Identifying reasons for relapse, reassessing readiness to change to } \\
\text { enter at appropriate stage, supporting another attempt and developing a } \\
\text { more effective smoking cessation plan }\end{array}$ \\
\hline
\end{tabular}


الملخص العربي

تأثير البرنامج التذخلي القائم على تطبيق نموذج نظرية التغييرعلى تلخين السجائر بين الطلاب الذكور في المدارس الثانوية الفنية بمدينة الزقازيق

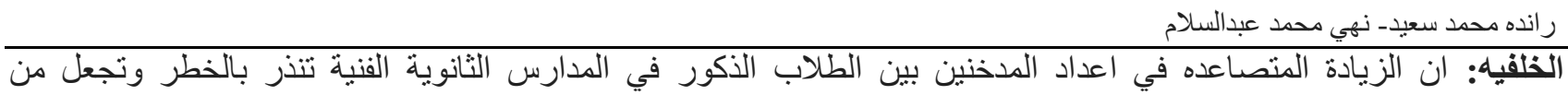
الضروري بذل المزيد من الجهود في مساعدة هذا القطاع من المر اهقين على الإقلاع عن التدخين. ان التنخلات المبنية على الاستر اتيجيات السلوكية المعرفية واعدة في الاقلاع عن التدخين بين المراهقين, وقد طبقت هذه الدراسه نموذج نظرية التغيير و وضعت سؤلا بحثيا هو هل تطبيق هذا النموذج سوف يغير سلوك المدخنين المر اهقين. الاهداف:و تهدف هذه الدراسه الي تقييم تأثير البرنامج التدخلي القائم على تطبيق نموذج نظرية التغييرعلى المعرفة باضرار التدخين ومخرجات نموذج نظرية التغييرو هي مر احل التغيير السلوكي, عمليات التغيير المعرفيه و السلوكيه، التوازن القراري, و الكفاءة الذاتية بين طلاب المدارس الثنانوية الفنية بالز قازيق.

المنهجيه وطرق البحث: أجريت در اسة شبه تجريبية علي المدخنين الذكور في مدرستين ثانويتين فنيتين نم اختيار هما عشو ائياً من مدينة الزقازيق, حيث استخدمت احدي المدرستين كمجموعة تجريبية والأخرى كمجموعة ضابطة ـ تلقت المجموعة التجريبية تدخلات مبنيه علي تحديد مرحلة تغيير السلوك في صورة المشورة الجماعية تلتها المشورة الهاتفيه الفردية لمدة 10 أثهر. كان تقييم التدخل من خلال الاستبيانات التي يجاب عنها ذاتيًا والتي تقِّم المعرفة باضر ار التدخين ومخرجات نموذج نظرية التغيير. النتائج: بعد التدخل، وجد ان عدد أكبر من المشاركين في المجموعة التجريبية (32\%) قد تقدمو امن المر احل الأدنى إلى المر احل الاعلي من تغيير السلوك، مقارنةً بالمجموعة الضابطة(9و1\%). كما ان المشاركون الذين بلغوا مرحلة العمل/ المحافظه بلغو ا9و13\% في المجموعة التجريبية مقابل(9و 1\%) في المجموعة الضابطة. كذلك كان هناك اختلاف احصائي كبير بين المجموعتين في متوسط درجات كلا من المعرفة باضر ار التدخين، عمليات التغيير المعرفيه و السلوكيه، التوازن القراري, والكفاءة الذاتية.الخلاصه: كان هذا البرنامج التدخلي القائم على تطبيق نموذج نظرية التغيير فعالاً في تغيير سلوك المدخنين المر اهقين. 